\title{
THE READINESS OF FOREIGN WORKERS REGULATIONS IN THE ENGINEERING AND MEDICAL PRACTITIONERS SECTOR ENTERING THE ASEAN ECONOMIC COMMUNITY $\Omega$
}

\author{
Agusmidah, Mahmul Siregar and Mohammad Eka Putra \\ Faculty of Law, Universitas Sumatera Utara, Medan \\ E-mail: midahagus@gmail.com
}

\begin{abstract}
Protection of the domestic labor market and prevention of skilled foreign workers entry through negative list are not in accordance with free market principle of the ASEAN Economic Community (AEC) to be implemented in ASEAN countries such as Indonesia in the second half of 2015. However, restrictions are still practiced by some Indonesian government institutions, such as Ministry of Health for doctors, dentists, and nurses, the Ministry of Public Works for surveyors, and the Ministry of Tourism for tourism profesionals. Through literature study and legal analysis, it was found that foreign workers restriction by professional associations according to certain competency standards aims to prevent domestic work from being monopolized by skilled foreign workers in the AEC 2015 era.
\end{abstract}

Keywords: ASEAN Economic Community (AEC), Indonesian regulation, skilled foreign workers

\section{Abstrak}

Melindungi pasar kerja dalam negeri dan mencegah masuknya Tenaga Kerja Asing (TKA) terampil dengan menerapkan negative list tidak sesuai dengan iklim pasar bebas dalam Masyarakat Ekonomi ASEAN (MEA) yang akan diterapkan di negara ASEAN pada paruh kedua tahun 2015. Namun, restriksi masuknya TKA terampil nyatanya tetap dilakukan oleh lembaga-lembaga pemerintahan Indonesia, seperti Kemenkes untuk dokter, dokter gigi, serta perawat, Kementerian PU untuk surveying, dan Kementerian Pariwisata untuk bidang pekerjaan profesional pariwisata. Mengingat regulasi yang ketat justru tidak sesuai dengan iklim liberalisasi TKA terampil dalam kerangka MEA. Melalui studi kepustakaan dan analisis undang-undang, penelitian ini menemukan bahwa restriksi asosiasi profesi dengan standar kompetensi tertentu bertujuan mencegah pasar kerja dalam negeri dikuasai oleh TKA terampil dalam era MEA 2015.

Kata kunci: Masyarakat Ekonomi ASEAN (MEA), Peraturan Indonesia, TKA terampil.

Introduction

Many parties said Indonesia is ready to face AEC, but it is not few that said otherwise. It doesn't need to be debated for deciding who is the right between two of them. The important thing is knowing the condition of Indonesia to face AEC at this time accurately. ASEAN Free Market will bring the benefits and the challenges, including on health ${ }^{1}$ and engineering sector.

$\Omega \quad$ The research with PNBP USU T.A 2014/2015 funds with Agreement Letter of the assignment of research funds PNBP USU Number: 7377/UN5.1.R/KEU/2014, September 17, 2014

Anna Ulfah Rahajoe, "Dampak Pasar Bebas ASEAN terhadap Praktek Kardiologi di Negara-negara ASEAN,
The competition that grows on market climate generally will give directions on the action for being the best by optimizing all the potency.

International Labour Organization (ILO) considers that the liberalization of services and employment in Indonesia, especially for the immigration of foreign workers (TKA) has not been in all sectors, there was even a restriction on certain sectors, such as education, telecommunications, and banking. Whereas for sector of road construction experts, ritail trading busi-

Jurnal Kardiologi Indonesia, Vol. 29 No. I, January 2008, Jakarta: Perhimpunan Dokter Spesialis Kardiovaskular Indonesia, page 2-3. 
ness, air transport the regulation is more flexible. $^{2}$

To can be said ready to face the AEC, so Indonesia must repair itself minimal on the four sectors, those are: first, Indonesia potentially just enough as the supplier and raw material for industrialization in the ASEAN area, so the benefit that is gotten from natural resource wealth is minimal, but deficit of Indonesian merchandise trade balance is the biggest at this time than the other's ASEAN countries is increasing; second, widen the services trade deficit while increasing trade in goods; third, freeing the flow of the labor so Indonesia should anticipate to prepare a strategy for the potential influx of foreign workers; and the fourth, the investation comes to Indonesia from the inside and outside ASEAN. ${ }^{3}$

Especially for the third point is anticipating and preparing strategy because AEC potentially making many foreign workers who will enter Indonesian labor market, it can be done by preparing the rule on target. The right rule will be medium for reaching the chance on ASEAN free market climate. The chance of Indonesia on $\mathrm{AEC}$, there are: first, economic integration. $A E C$, direct or indirect opens the chance for Indonesia to fight on economic regional supporting economic integration for growing the economy on the country or the ASEAN area; second, ASEAN is world potential market, by realizing AEC so ASEAN will become the third biggest market area in the world that is supported by the third biggest amount of population ( $8 \%$ from the total population of the world) after China and India; third, ASEAN generally is exporter country, either natural resource-based product/agrobased products and electronic product; fourth, export destinations; fifth, open service sector especially tourism service, health, flight, and e-ASEAN, and logistic, al-

2 Chris Manning and Haryo Aswicahyo, Perdagangan di Bidang Jasa dan Ketenagakerjaan: Kasus Indonesia, Jakarta, 2012, page iii.

3 Humphrey Wangke, "Peluang Indonesia dalam Masyarakat Ekonomi ASEAN 2015", Info Singkat Hubungan Internasional, Vol. VI, No. 10/II/P3DI/Mei/2014, Jakarta: Pusat Pengkajian, Pengolahan Data dan Informasi (P3DI) Sekretariat Jenderal DPR RI, page 8. though is recognized countries that have developed this sector still limited, they are Singapore, Malaysia and Thailand. The chance of Indonesia in this sector is precisely the magnitude of the amount of labor, so potential to provide the sufficient labor; and the sixth, the flow of capital, where ASEAN becomes global investment destination. ${ }^{4}$

Thus the importance of the accuracy of a regulation to achieve the expected goals, the various regulations that related to the use of foreigner workers need to be assessed the relevance of ASEAN as a single market climate was carried by AEC, what should the government do on responsing to significant changes in circumstances that with the enactment of the MEA, in particular regarding the readiness to provide the right regulatory.

\section{Problems}

The problem on this research is how the government prepares the right regulations on the case of the use of foreign workers in the framework of the ASEAN single market in Asean Economic Community (AEC) or Masyarakat Ekonomi Asean (MEA). Detail of this problem is how the readiness of regulations at this time toward the liberalization of foreign worker that had agreed on forum ASEAN regional cooperation in the framework of ASEAN economic community in 2015 ?

\section{Research Methods}

This research is an analytical description with the use of statute approach. Through descriptive method will be described about the relationship between free market policies in the AEC particularly concerning the free flow of skilled workers that will be faced by Indonesia related to the readiness of Indonesia in preparing sets of rules concerning requirements and procedures for the use of foreign workers according to the needs of APEC dynamics which will take effect in 2015. For getting the maximum results, it needs additional primary data

\footnotetext{
4 Kementerian Perdagangan RI, 2015, Menuju Asean Economic Community, Jakarta: Departemen Perdagangan Republik Indonesia, page 74-78.
} 
that is acquired by interview as directed an indepth interviews using the guidelines to businesses, in this case is selected Indonesian Employers Association of North Sumatra and Manpower Office of North Sumatra as part of the skateholders that are directly related to the use of foreign workers.

\section{DISCUSSION}

\section{Selective Policy in the using of Foreign Wor- kers}

The usage policy of foreign workers is done very carefully considering the needs of their jobs for it's own citizens are also very large, moreover the jobs available are not balanced. To achieve this goal, the use of foreign workers should go through the government's permission. Permission is dispensed from a ban. Regarding the hiring of foreign workers is prohibited, but to fill the void labor because certain skills are still permitted to use foreign workers. Then for it was given permission to hire foreign workers, with supervision in accordance with the regulations set by the government. ${ }^{5}$ This is called as Selective Policy, is a policy that starts from the view that the utilization of foreign workers must be implemented to optimize the needs and protection of job's chance in the country, therefor the use of foreign workers is justified only by the expertise or skill with the objective of technology transfer will occur. ${ }^{6}$

In the implementation, permit the use of foreign workers is set by law. When the enactment of Law No. 3 of 1958 regarding the placement of foreign workers, permission to hire foreign workers must be obtained from the minister of labor, employing foreign workers without permission is prohibited (article 2, paragraph 1). Furthermore, affirmed in a presidential dec-

See also Budi S.P Nababan, "Perlunya Perda Tentang Retribusi Perpanjangan Izin Mempekerjakan TKA di Tengah Liberalisasi Tenaga Kerja Masyarakat ASEAN 2015”, Jurnal Rechtsvinding, Vol. 3 No. 2 August 2014, Jakarta: BPHN Kemenkum HAM, page 297-309.

6 Vidya Prahassacitta, "Dualisme Pandangan Mahkamah Agung Mengenai Status Hukum TKA Kajian Putusan Mahkamah Agung Nomor 595K/PDT.SUS/2010 dan Nomor 29PK/PDT.SUS/2010", Jurnal Yudisial, Vol. 7 No. 2, August 2014, Jakarta: Komisi Yudisial Republik Indonesia, page 129. ree number 75 of 1995 about he employment of foreign nationals migrants (TKWNAP) that permission to employ TKWNAP/TKA is granted by the Minister of Labor or appointed official (article 7, paragraph (2). Now with Law no. 13 of 2003 on the Labor Law (UUK), stipulates that every employer who employs foreign workers are required to have written permission from the Minister responsible for the field of employment, or of a designated official.

Looking at the substance of the arrangement, there are 2 (two) kinds of licenses, which permit employs a foreign workers and permit casual work. By type, there are 3 (three) kinds of work permits of foreign workers, there are the work permits of foreign workers (new), permission to hire foreign workers for the first time, extension of work permits of foreign workers, foreign workers and work permits (for the position transfer). The permission is granted to move the new position. The institution that authorized to exercise supervision over the company and labor employing the foreign workers is the Ministry of Labor as the agency which has the permission placement of foreign workers, while the labor inspection as a stranger is the authority of the $\mathrm{Di}$ rectorate General of Immigration in charge of supervising the moment when they enter, likewise the activities are carried while in the territory of Indonesia.

On the progress, Law No. 3 of 1958 is repealed because of the enactment of Labor Law. Especially with regard to the use of foreign worker is stipulated in chapter VIII from the article 42 until article 49 . The article 42 paragraph 1 set need permission to use foreign workers. In the explanation of article 42 stated that the purpose of the holding licensing the use of labor of foreign nationals meant that employment of foreign nationals are implemented selectively in order to empower Indonesian workers optimally. As for article 44 paragraph 1 set foreign workers employer shall comply with the regulations and competency standards applicable. Article 44 is correlated with the explanation of article 42 which states that the use of foreign workers carried out selectively, 
it will occur the utilization of the optimal Indonesian's worker. Based on that idea legislator then set a number of conditions for the company in the form of licensing, standards or competency skills, a limited time period, and the obligation to pay compensation for the use of foreign workers for entry into state coffers.

The positions are allowed for foreign workers has been regulated in several laws, among others, the Ministry of Manpower and Transmigration Republic of Indonesia Decree number 359 of 2013 about the position that can be occupied by foreign workers in the category of industrial manufacturing base classes instead of metal goods machinery and equipment. There is also a regulation of the Minister of Energy and Mineral Resources of Indonesia no. 31 of 2013 about conditions and procedures for the use of foreign workers and the development of Indonesian workers in the oil business activities and natural gas. Provisions on the type of position is thus made according to sectors and areas of work in each department.

Regarding the implementation of the provisions of Labor Law article 49, is required the President Regulation no. 72 of 2014 which regulates the use of foreign workers as well as the implementation of education and manpower training companion. Based on article 11 of President Regulation no. 72 of 2014 stated that the obligation for employers pointed Indonesian workers as a labor companion and providing education and training in accordance with the qualification positions occupied by foreign workers. Exception to this provision applies to foreign workers who occupied the position of director/commissioner. Article 12 confirms that designation Indonesian labor as a labor companion for the transfer of technology and skills transfer. Training for the Indonesian labor force can be done in the country and/or abroad, if it has been implemented it will receive a training certificate of competence in accordance with legislation existing.

\section{Protection Policy Evaluation by Restrictions Through Regulation}

The restriction conducted to control the entry of foreign workers through legislation on the grounds of national interest-protecting the rights of local workers to access skilled labor market. This type of restriction called as institutionalized restriction. ${ }^{7}$ Institutionalized restriction in the concept of state law which can be done by providing legislation that regulates the restriction or by providing judiciary. Some terms and conditions of the permission for the entry of foreign workers, such as mastering Indonesian can be one of the way to restrict the entry of foreign workers. But unfortunately this is paradox with free market climate that was built in the AEC.

Protection for the entry of foreign workers by the restriction through legislation is not the best way to prevent the entry of foreign workers to Indonesia. Actually, something that should be a priority is improving the ability of Indonesian human resources, ${ }^{8}$ so they will have ability and skills in accordance with labor market needs either through intensification and extensification of Training Center as well as optimizing the Profession Standards Organization through the adoption of standardization applied. ${ }^{9}$

In the context of the development of Human Resources, Indonesia needs to create rules to encourage the increased competitiveness of the local workers for skilled jobs. ${ }^{10}$ The

7 Widodo Ekatjahjana, "Menjaga Peradilan Partai Politik Pemilu dalam Sistem Ketatanegaraan Indonesia”, Jurnal Konstitusi, Vol. 2 No.1, June 2009, Bengkulu: PKKFaculty of Law Universitas Bengkulu, page 85.

8 Singapore is a country that is most ready with its human resources look at Pudjo Utomo, "Kesiapan Sumber Daya Manusia (Tenaga Kerja) Bidang Kostruksi di Indonesia Menghadapi Masyarakat Ekonomi Asean", Jurnal Ilmiah Ilmu Hukum QISTIE, Vol. 7 No. 2, November 2014, Semarang: Faculty of Law Universitas Wahid Hasyim Semarang page 92.

9 Masnur Tiurmaida Malau, "Aspek Hukum Peraturan dan Kebijakan Pemerintah Indonesia Menghadapi Liberalisasi Ekonomi Regional: Masyarakat Ekonomi ASEAN 2015”, Jurnal Rechtsvinding, Vol. 3 No. 2, August 2014, Jakarta: BPHN Kemenkumham RI, page 176.

10 Muhammad Fadli, "Optimalisasi Kebijakan Ketenagakerjaan dalam Menghadapi Masyarakat Ekonomi ASEAN 2015”, Jurnal Rechtsvinding, Vol. 3 No. 2, August 2014, stated among other with job training and maximize the functions of the National Professional Certification. It is also the toughest challenge for education, read in Benedicta Evienia P, B. Elnath Aldi, Astri Madhyaratri, 
basic things is a large population ${ }^{11}$ is not proportional to the number of skilled workers such as engineers, architects, nurses, surveying, accountants, doctors, dentists, and professionals in tourism, all of its has been agreed in MRA. ${ }^{12}$

World Bank research found a big gap in the quality of Indonesian skilled workers. Mentioned that the biggest gap is the use of English (44\%), computer usage skills (36\%), behavioral skills $(30 \%)$, critical thinking skills $(33 \%)$, and basic skills $(13 \%) .{ }^{13}$ Thus, Indonesia is still not ready to compete for the job market of ASEAN. ${ }^{14}$ Here is the policy of protection and restriction technical institution we picked up, especially in engineering and medical expertise (doctors).

\section{Field of Engineering}

ASEAN MRA agreement in the engineering services signed on December 9, 2005. In contrast to the surveying sector and accounting sector, MRA in the engineering sector has been signed by ten countries and no longer is a framework. Indonesia has had Engineering Law since February 2014 through Law No. 11 of 2014. In Article 1 paragraph 1 stated that Engineering is engineering activities by using the expertise and skills based on the mastery of science and technology to increase the added

“Pandangan Pelaku Pendidikan Universitas Terhadap Pemberlakuan Masyarakat Ekonomi ASEAN 2015, Bina Ekonomi Majalah Ilmiah, Vol. 18 No. 2, August 2014, Bandung: Faculty of Economics Universitas Parahyangan page 106

11 Erliz Nindi Pratiwi and Rifa Atun Mahmudah, "Peningkatan Daya Saing Tenaga Kerja Indonesia Melalui Korelasi Input Penunjang Tenaga Kerja dalam Menghadapi MEA 2015", Economics Development Analysis Journal, Vol. 2 No. 2, May 2013, Semarang: Faculty of Economics Universitas Negeri Semarang, page 1-2.

12 See also in Anung Pramudyo, "Mempersiapkan Sumber Daya Manusia Indonesia dalam Menghadapi Masyarakat Ekonomi ASEAN Tahun 2015", Jurnal Bisnis Manajemen dan Akuntansi, Vol. II No. 2, September 2014, Yogyakarta: Akademik Majemen Administrasi YPK, page 93.

13 Makmur Keliat, Asra Virgianita, Shofwan Al Banna Choiruzzad, Agus Catur Aryanto Putro, 2013, Pemetaan Pekerja Terampil Indonesia dan Liberalisasi Jasa ASEAN, Laporan Penelitian, ASEAN Study Center Universitas Indonesia in cooperation with the Ministry of Foreign Affairs, Jakarta, page 45.

14 Tessa Hendrika Kartika, "Kesiapan Indonesia dalam Merealisasikan Integrasi Tenaga Kerja Terampil pada Masyarakat Ekonomi ASEAN Tahun 2015", Jurnal Ilmiah Universitas Bakrie, Vol. 3, No. 03, 2015, Jakarta: Universitas Bakrie. value and efficiency sustainably by paying attention to safety, health, benefit, and social welfare and environmental sustainability, while the engineer is a term that is intended for person who has a professional degree in the field of engineering.

Regarding foreign engineers set out in Article 18 of Law No. 11 of 2014 the settings, as follows :

(1) Foreign Engineers can only perform engineering practice in Indonesia in accordance with the needs of human resources in science and technology of national development set by the Government.

(2) Foreign engineers who perform engineering practice in Indonesia as referred in paragraph (1) must have work permits of foreign workers in accordance with the provisions of the legislation.

(3) In order to obtain a work permit as referred in paragraph (2), Foreign Engineers must have the Engineers Registration Letter from IEI (PII) by letter of registration or certificate of competency Engineers according to their national law.

(4) In the case of foreign engineers do not have the registration letter or certificate of competency Engineers according to their national law as referred in paragraph (3), Foreign Engineers must qualify as referred in Article 11.

Based on Article 11 which provides that an engineer must have a Certificate of Competence Engineering gained after passing competency test conducted by professional certification institution in accordance with the provisions of the legislation. Law No. 11 of 2014 on engineering will support the improvement of Indonesian undergraduate engineering competence to go down as a professional engineer for the community. By 2015, all engineering undergraduate are required to attend the professional competence school to earn the title of "Engineer" after being "Bachelor of Engineering". The existence of professional education is expected graduates of engineering program have high competitiveness mainly with the foreign 
graduates. Hopefully, with increased of competence, the engineer's role can be further improved in the national industry. Restriction and protection of the entry of foreign engineers conducted by setting a number of requirements and permits that must be held as arranged in Article 18 and 19 of Engineering Law, non-compliance with this provision will get administrative sanctions (Article 21).

ASEAN Federation of Engineering Organisations (AFEO) released data on the number of Indonesian professional engineers is only about 9,000 people. The number was still less when compared with other ASEAN countries, such as Malaysia (11,170 people), Thailand $(23,000$ people), and the Philippines (14,250 people). Not only that. Qualitatively, Indonesian professional engineers still a few who meet the standards of Mutual Recognition Arrangements (MRA) - standard which aims in service trade and determine the general requirements liberalization of the services sector in the ASEAN region. ${ }^{15}$ This condition will be the the gateway for foreign engineers, beside the skills and financial capacity is still low.

\section{Field of Medical Practitioners}

ASEAN MRA on Medical Practitioners signed in Cha am, Thailand on February 26, 2009 simultaneously with MRA signatory for the dental practitioners services and accounting services (accountancy services According to the Centre for International Trade Thailand (2012), the quality of Indonesian professional medical practitioners (doctors) placed on medium quality and had to compete with the Philippines and Vietnam. This situation is exactly the situation faced by the nursing profession. Besides, the OECD report states that the ratio between the number of doctors and nurses in Indonesia is still far behind compared to other countries. The ratio of doctors to population stands at 0.3 per 1,000 population. Far behind compared

15 Direktorat Jenderal Kerjasama ASEAN Kementerian Luar Negeri RI, 2015, Potret Daya Saing Insinyur Indonesia: Membidik Peluang MEA, Jakarta: Masyarakat ASEAN, page 6 . with Singapore ratio (1.7), Malaysia (1.2), and the Philippines (1.1)..$^{16}$

Lack of medical personnel, especially general practitioner and medical specialists indicated their demand data in 2014 with the data availability in 2013, obviously Indonesia in the position of the shortage of doctors. Availability of medical specialists is estimated as many as 20,602 people (2013), while its needs as many as 29,452 people (2014), thus experiencing a shortage as many as 8,999 medical personnel. The general practitioner is not much different, of the estimate needs as many as 117,808 (2014) only available as many as 85,405 (2013) thus experiencing a shortage as many as 27,599 doctors. ${ }^{17}$

Medical Education Bill has been designed in 2011. Implementation of the Medical Act requires coordination between the Ministry of Health, Ministry of National Education, IMC (KKI) and other medical professional organizations. This law is expected to be a solution for Indonesia to equate competence with other ASEAN countries.

Besides that, in order to harmonize the rules in ASEAN, the government needs to consider and referring to health law, practice of medicine law and health personnel law. Without referring to interrelated law, comprehensive rules in an effort to maximize the benefits of the ASEAN market will be difficult to achieve. But in fact, Indonesia is a country that makes medical services sector is quite loose. In Thailand, the government requires foreign doctor to master the local language. While in Indonesia from the business side of health care, foreign companies can hold shares up to $70 \%$, even allowed to set up a hospital on the condition while still providing $25 \%$ quota for underprivileged patients.

Meanwhile, in terms of flow of foreign doctors, the government has made regulations on foreign doctors in Indonesia. This regulation

Makmur Keliat, op.cit, page 56

17 Tri Rini Puji Lestari, "Peran UU Nakes dan Tantangan Masalah Kesehatan Indonesia", Info Singkat Kesejahteraan, Vol. VI, No. 18/II/P3DI/Sep/2014, Jakarta: Pusat Pengkajian, Pengolahan Data dan Informasi (P3DI). Sekretariat Jenderal DPR RI, page 10. 
lays out in detail, the documents required and how foreign doctors who can be accommodated in Indonesia. Foreign doctors must obtain temporary registration letter (STR) from the the Indonesian Medical Council (IMC/KKI). To get STR, IMC will conduct examination from the the relevant competence. After that, foreign doctors eligible to apply for a license to practice (SIP) from the the Indonesian Doctors Association (IDI). STR and SIP shall be updated annually.

Regulation of foreign workers in the health sector is contained in Law No. 36 of 2009 on Health (Article 21), Law No. 44 of 2009 on Hospital (Article 14), Law No. 29 of 2004 on medical practice (Article 30), Law No. 6 of 2011 on immigration, Council Regulation No. 17/KKI/ KEP/IV/2008 on Guidelines procedures of temporary registration and conditional registration of foreigners doctors and dentists, Council Regulation No. 157/KKI/PER/XII/2009 on Procedures for registration of ASEAN doctors and dentists who will practice medicine in Indonesia, health ministry regulations 317/2010 on Empowerment of foreign workers in Indonesia (Article 11), Minister of Health Decree No. 2574/ Menkes/SK/XII/2011 on Licensing Coordination Team of Medicals foreigners in Indonesia, health ministry regulations No. 2052 of 2011 on Licensed medical practices and the implementation (Article 17-18). Legislation on regulating foreign workers in health sector is already quite complete, but the dissemination and implementation that had not been optimal. ${ }^{18}$

\section{Conclusion}

Labor regulations, especially regarding the use of foreign workers in its development was born to protect and securing the labor market from the domination of foreign citizens. Now with the global free market and the free market of ASEAN, especially protection policies and restrictions is also still a Scientific Journal

18 Tri Juni Angkasawati and Turniani Laksmiarti, "Peraturan Perundangan dalam Pendayagunaan Tenaga Kesehatan Warga Negara Asing (TKWNA) di Indonesia", Buletin Penelitian Sistem Kesehatan, Vol. 17 No. 4, October, 2014, Surabaya: Pusat Humaniora, Kebijakan Kesehatan dan Pemberdayaan Masyarakat, page 343. of Universitas Bakrie main reason made the relating rules. Each of these technical expertise sector has been incorporated in the form of professional organization and establish standards of competence as well as some requirements and permits for the entry of skilled foreign workers. This action is considered reasonable because other countries also do the same, but it should be noted, have the Indonesian human resources has the competency-based international standards with an adequate number from its population, besides also involves technological and financial capabilities that causes Indonesian engineers are not able to do larger projects in their own country.

\section{Suggestion}

Tightening regulations for the entry of skilled foreign workers is only one restriction's instrument under the authority of the state, but shoul put forward the strategic and structural policies in order to Indonesian education graduate dominate ASEAN competency-based standards, so the domestic labor market is controlled by its own human resources.

\section{References}

Angkasawati, Tri Juni and Turniani Laksmiarti. "Peraturan Perundangan dalam Pendayagunaan Tenaga Kesehatan Warga Negara Asing (TKWNA) di Indonesia". Buletin Penelitian Sistem Kesehatan, Vol. 17 No. 4, October 2014, Surabaya: Pusat Humaniora, Kebijakan Kesehatan dan Pemberdayaan Masyarakat;

Anung Pramudyo. "Mempersiapkan Sumber Daya Manusia Indonesia dalam Menghadapi Masyarakat Ekonomi ASEAN Tahun 2015". JBMA, Vol. II No. 2, September 2014;

Direktorat Jenderal Kerjasama ASEAN Kementerian Luar Negeri RI. 2015. Potret Daya Saing Insinyur Indonesia: Membidik Peluang MEA. $7^{\text {th }}$ Edition. Jakarta: Masyarakat ASEAN;

Ekatjahjana, Widodo. “Menjaga Peradilan Partai Politik Pemilu dalam Sistem Ketatanegaraan Indonesia". Jurnal Konstitusi. Vol. 2 No. 1. June 2009. Bengkulu: PKK-Faculty of Law, Universitas Bengkulu; 
Fadli, Muhammad. "Optimalisasi Kebijakan Ketenagakerjaan dalam Menghadapi Masyarakat Ekonomi ASEAN 2015". Jurnal Rechts Vinding, Vol. 3 No. 2, August 2014, Jakarta: BPHN Kemenkumham RI;

Kartika, Tessa Hendrika. "Kesiapan Indonesia dalam Merealisasikan Integrasi Tenaga Kerja Terampil pada Masyarakat Ekonomi ASEAN Tahun 2015". Jurnal Ilmiah Universitas Bakrie, Vol. 3, No. 03, 2015, Jakarta: Universitas Bakrie;

Keliat, Makmur; Asra Virgianita, Shofwan Al Banna Choiruzzad, Agus Catur Aryanto Putro. 2013. Pemetaan Pekerja Terampil Indonesia dan Liberalisasi Jasa ASEAN. Laporan Penelitian ASEAN Study Center Universitas Indonesia Bekerjasama dengan Kementerian Luar Negeri RI. Jakarta;

Lestari, Tri Rini Puji. "Peran UU Nakes dan Tantangan Masalah Kesehatan Indonesia". Info Singkat Kesejahteraan. Vol. VI No. 18/ II/P3DI/Sep/2014. Jakarta: Pusat Pengkajian. Pengolahan Data dan Informasi (P3DI) Sekretariat Jenderal DPR RI;

Malau, Masnur Tiurmaida. “Aspek Hukum Peraturan dan Kebijakan Pemerintah Indonesia Menghadapi Liberalisasi Ekonomi Regional: Masyarakat Ekonomi ASEAN 2015". Jurnal Rechtsvinding, Vol. 3 No. 2. August 2014. Jakarta: BPHN Kemenkumham Rl;

Manning, Chris and Haryo Aswicahyo. 2012. Perdagangan di Bidang Jasa dan Ketenagakerjaan: Kasus Indonesia. Jakarta: ILO;

Nababan, Budi S.P. “Perlunya Perda Tentang Retribusi Perpanjangan Izin Mempekerjakan TKA di Tengah Liberalisasi Tenaga Kerja Masyarakat ASEAN 2015". Jurnal Rechtsvinding, Vol. 3 No. 2 August 2014. Jakarta: BPHN Kemenkumham RI;

P, Benedicta Evienia; B. Elnath Aldi, Astri Madhyaratri. "Pandangan Pelaku Pendidikan Universitas Terhadap Pemberlakuan Masyarakat Ekonomi ASEAN 2015". Bina Ekonomi Majalah Ilmiah, Vol. 18 No. 2, August 2014, Bandung: Faculty of Economics Unpar;

Prahassacitta, Vidya. "Dualisme Pandangan Mahkamah Agung Mengenai Status Hukum TKA Kajian Putusan Mahkamah Agung No. 595K/PDT.SUS/2010 dan No. 29PK/PDT. SUS/2010”. Jurnal Yudisial, Vol. 7 No. 2. August 2014. Jakarta: Komisi Yudisial;
Pramudyo, Anung. "Mempersiapkan Sumber Daya Manusia Indonesia dalam Menghadapi Masyarakat Ekonomi ASEAN Tahun 2015”. Jurnal Bisnis Manajemen dan Akuntansi, Vol. II No. 2, September 2014. Yogyakarta: Akademik Majemen Administrasi YPK;

Pratiwi, Erliz Nindi dan Rifa Atun Mahmudah. "Peningkatan Daya Saing Tenaga Kerja Indonesia Melalui Korelasi Input Penunjang Tenaga Kerja dalam Menghadapi MEA 2015". Economics Development Analysis Journal, Vol. 2 No. 2, May 2013;

Rahajoe, Anna Ulfah. "Dampak Pasar Bebas ASEAN terhdap Praktek Kardiologi di Negara-negara ASEAN". Jurnal Kardiologi Indonesia, Vol. 29 No. I, January 2008;

Republik Indonesia, Kementerian Perdagangan. 2015. Menuju Asean Economic Community. Jakarta: Departemen Perdagangan Republik Indonesia;

Utomo, Pudjo. “Kesiapan Sumber Daya Manusia (Tenaga Kerja) Bidang Kostruksi di Indonesia Menghadapi Masyarakat Ekonomi Asean". Jurnal Ilmiah Ilmu Hukum QISTIE, Vol. 7 No. 2, November 2014. Semarang: Faculty of Law Universitas Wahid Hasyim Semarang;

Wangke, Humphrey. "Peluang Indonesia dalam Masyarakat Ekonomi ASEAN 2015". Info Singkat Hubungan Internasional, Vol. VI, No. 10/II/P3DI/Mei/2014. Jakarta: Pusat Pengkajian, Pengolahan Data dan Informasi (P3DI). Sekretariat Jenderal DPR RI. 